\title{
ADOK-KAPOK, AVAGY EGY SAJÁTOS ADÁSVÉTEL PETRONIUS SATYRICONJÁBAN
}

\begin{abstract}
A klasszikus kori irodalmi latin nyelv és a római jogtudósok által kidolgozott jogi latin nyelv közti kölcsönhatás az irodalom és római jog határán elhelyezkedő, kevéssé kutatott terület, amely számos megválaszolatlan kérdést rejt magában. A jogi szakkifejezések felbukkanása a klasszikus kori irodalmi nyelvben a joghoz nem értők számára különös jelenségnek számított, amely a szélesebb olvasóközönség érdeklődését éppen homályossága és gyakori kétes értelmezhetősége révén keltette fel. Tanulmányomban a Petronius Satyriconjának XII-XV. caputjában szereplő jogi szakkifejezéseket vizsgálom a jogi tényállás tisztázásán keresztül, választ keresve azok tényleges funkciójára. A forumon játszódó jelenet elemzése során a római jog precizitása és a petroniusi humor közti ellentét feloldásának kulcsát az írói szándék feltárása jelenti, amely a jogi latin nyelvet sajátos módon illeszti művébe.
\end{abstract}

Kulcsszavak: Petronius: Satyricon, szatíra, római jog, jogi latin nyelv, jog és irodalom kapcsolata, jog mint a humor forrása

A Nero-kori római író, ${ }^{1}$ Petronius Satyriconjának fennmaradt töredékei, bár első ránézésre a szatírák megszokott hangulatát idézik, legyen bennük szó akár egy forró napon tartott szónoki beszédről, vagy a nem túl előírásszerủen tartott gyászról, közelebbről szemügyre véve meglepően sok jogi szituációt tartalmaznak, az örökségvadászoktól egészen egy lopott pallium eladásáig. Petroniust ismerve korántsem meglepő, hogy jeleneteiben jogi szempontból ${ }^{2}$ nézve sincs semmi rendben: ${ }^{3}$ jogszolgáltatás az este leszállta után, ügyvédeknél elhelyezett letét, vagy éppen a korrupt „igazságszolgáltatás”. Egyszóval számos anomália üti fel a fejét, amelyeken a római jog kutatóinak is megakadhat a tekintete.

A XII-XV. caputban egy érdekes jelenetnek lehetünk tanúi, amely egy forumon játszódik, Encolpios elbeszélésében. Encolpios és Ascyltos úgy döntenek, hogy túladnak a lopott palliumon, csakhogy éppen eredeti tulajdonosának igyekeznek azt eladni. Ekkor pillantják meg vevőjelöltjüknél azt az elhagyott tunicát, melybe aranyukat korábban elrejtették. Mi sem természetesebb, mint egyenesen a törvény és jog fegyverével harcolni törvényes tulajdonukért. A pallium lopott voltáról és a nem túl jóhiszemű adásvételről már-már meg is feledkezne az olvasó, amikor Encolpios a pert emlegeti annak érdekében, hogy „ami jog szerint az ő tulajdonuk” visszaszerezzék, de javaslata

1 G. B. Conte: Latin Literature. A History. Baltimore - London 1994. 453 skk.

2 A jogintézmények leírása elsőre különösnek tűnhet, mely egy másfajta szemléletmódot és olvasást igényel. Vö. K. Verboven: A Funny Thing Happened on My Way to the Market. Reading Petronius to Write Economic History. In: J. R. W. Prag - I. D. Repath (eds.): Petronius. A Handbook. Oxford 2009. 126 skk.

${ }^{3}$ Petronius Satyriconja egyrészt töredékes jellege, másrészt gyakran homályos utalásai miatt sem könnyen érthető mü, ahogy Conte fogalmaz „few masterpieces of world literature are so shadowy as this”. Lásd Conte: i. m. (1. jegyz.) 454. 
a törvényes út igénybevételére süket fülekre talál. Ascyltos inkább kerülőútra tereli az ügyet, és kétséget sem hagy bennünk, hogy a jogi út nem vezet semmi jóra. Csakhogy a kerülőútnak is megvan a maga buktatója, és eladóink lelepleződnek. Ezek után a jogi út már elkerülhetetlennek látszik, de a sors mégis különös fordulatot vesz.

A Satyricon cselekménye feltehetően Petronius saját korában játszódik, közelebbről a késői Nero-korra tehető. ${ }^{4}$ Ez a római jogtudomány korszakai közül a korai klasszikus római jog és egyben a principátus korai időszakát jelenti. ${ }^{5} \mathrm{~A}$ római jog a klasszikus korban érte el tökéletes formáját a jogtudósok munkájában, ${ }^{6}$ és ezzel párhuzamosan a latin nyelv is ebben a korszakban érkezett el tetőpontjára. ${ }^{7}$ Ez a tökéletesség azonban más formát ölt Petroniusnál.

A petroniusi nyelvhasználat kapcsán Trimalchio lakomájának nyelvezete tekinthető modellnek, ${ }^{8}$ ahol megfigyelhető, hogy a latin nyelv szabályai, legyen szó alaktanról vagy mondattanról, nem feltétlenül valósulnak meg. ${ }^{9}$ Conte kiemeli, hogy a Satyricon nyelvezete tudatosan szerkesztett és Petronius müvészi fogásainak egyik legmeghatározóbb típusa, mely a vulgáris kifejezéseket és nyelvtant állítja a reflektorfénybe. ${ }^{10} \mathrm{~A}$ tartalom tekintetében legtöbbször az össze-vissza beszélés a találó kifejezés a szereplők mondanivalójára. ${ }^{11}$ Elbeszélőnk, ${ }^{12}$ Encolpios azzal henceg többször is, hogy müvelt. ${ }^{13}$ A müben viszont ezt nem igazán látjuk bizonyítottnak. Kérdés, hogy vajon Encolpios titokzatos mủveltsége a jogban való jártassága lehet-e, amelyet éppen a jogi latin szaknyelv pontos és precíz használata tükrözne ebben a jelenetben.

${ }^{4}$ A Nero-korra a szakirodalom általában egy Tacitus hely alapján következtet. Tacitus Annalesében (Tac. Ann. XVI, 18-19) említést tesz egy tanácsadóról a császári udvarban, egy bizonyos Petroniusról, akit a császár öngyilkosságra kényszerített Kr. u. 66-ban. Ez az uralkodó minden bizonnyal Nero lehetett, aki Kr. u. 54 és 68 között uralkodott. A müben szereplő leírások alapján a történet cselekménye is ebben a korban játszódik. Lásd C. Vout: The Satyrica and Neronian Culture. In: Prag-Repath: i. m. (2. jegyz.) 101; Conte: i. m. (1. jegyz.) 453 sk.; K. F. C. Rose: The Date and Author of the Satyricon. Leiden 1971. 38 sk.; J. P. Sullivan: The Satyricon of Petronius. A Literary Study. Bloomington - London 1968. 22; E. Courtney: A Companion to Petronius. Oxford 2001. 5 skk.

${ }^{5}$ Földi A. - Hamza G.: A római jog története és institúciói. Budapest $2014^{19} .87$.

${ }^{6}$ Földi-Hamza: i. m. (5. jegyz.) 15.

7 Adamik B.: A latin nyelv története. Az indoeurópai alapnyelvtől a klasszikus latinig. Budapest 2009. 195 skk.

${ }^{8}$ Ez az egyetlen hosszabb, összefüggő rész, amely fennmaradt, így ebből lehet a leginkább a Satyricon nyelvezetére következtetni. Lásd Conte: i.m. (1. jegyz.) 456; Sullivan: i. m. (4. jegyz.) 23 skk.

9 Conte: i. m. (1. jegyz) 456 skk.; Adamik: i. m. (7. jegyz.) 213 sk.

${ }^{10}$ Conte: i. m. (1. jegyz.) 456 skk.; V. Rimell: Letting the Page Run on Poetics, Rhetoric, and Noise in the Satyrica. In: Prag-Repath. i. m. (2. jegyz.) 77 sk.

${ }^{11}$ Conte: i. m. (1. jegyz.) 455 sk.

12 Conte kiemeli, hogy az egész Satyricon narratológiai szempontból is sajátos, tekintettel arra, hogy a narrátor egy tudatosan szerkesztett, retorikailag megkomponált szerepben tűnik fel. Kívülállóként, mégsem teljesen objektív szemszögből beszéli el a történetet. G. B. Conte: The Hidden Author. An Interpretation of Petronius' Satyricon. Berkeley - Los Angeles 1996. 17 skk.

13 Lásd Conte: i. m. (12. jegyz.) 2 skk., 193 skk. Vö. Rimell: i. m. (10. jegyz.) 70. 
Petronius a jogi latin nyelv szakkifejezéseit - ahogy más szaknyelvekét is ${ }^{14}$ - felhasználja, hogy azok a humor forrásaként szórakoztassák az olvasót. A jogi szakkifejezéseken túl a szituáció is jogi szempontból releváns, konkrét jogintézmények jelennek meg a pallium eladásával kapcsolatban. Felmerül a kérdés, hogy egyedi műfajú szatírájában a jog ábrázolása is különleges-e a többi szatíraírónál látható ábrázolásmódokhoz képest. ${ }^{15}$

A szatíra müfajában alkotóknál megfigyelhető, hogy müveikben a jogi szakkifejezések használata különböző funkciót tölt be. Valamennyi szatíraíró közkedvelt témája az örökségvadászat, illetve bizonyos erkölcsi (gyakran büntetőjogi vonatkozású) kérdések. Duncan Cloud foglalkozik a kérdéskörrel Persius, Iuvenalis és Horatius szatírái kapcsán. Nem említi azonban sem Luciliust, sem Sulpiciát, sem Petroniust. Közülük Petronius az, aki szatíráiban számos joggal kapcsolatos jelenetet felvonultat.

A legkevesebb szakkifejezés Persiusnál található, aki erkölcsi szemszögből közelíti meg a kérdést. Persius csak alkalmanként használja, pusztán ábrázolás eszközeként a „jogi képeket”,16 mintegy a szerkezet kohéziós elemeiként. Iuvenalis sokkal komplexebben ábrázolja a jogot Persiusnál, de alapjaiban ugyanaz a tendencia figyelhető meg nála is, az, hogy a precíz és pontos ábrázolás szónoki fikcióba torkollik. ${ }^{17}$ Mielőtt valaki a jogtörténész szemével vetne egy pillantást Iuvenalis művére, figyelembe kell venni, hogy a leírt tények valóságalapja nem mindig bizonyítható egyértelműen. Iuvenalis a görög jog és római jog elemeit vegyítve azok szabályait tévesen használja. Konkrét jogforrásokra hivatkozik műveiben, így pl. lex Iulia de adulteriis, lex Cincia, Lucius Roscius-féle törvény stb. ${ }^{18}$ Iuvenalisnál elsődlegesen a büntetőjogi kérdések merülnek fel, ${ }^{19}$ de nem annyira etikai szemszögből, mint Persiusnál. ${ }^{20}$ A jogi szakkifejezések legmarkánsabban Horatius szatíráiban jelennek meg, aki általában a jogi-szakrális töltet kedvéért csempészi műveibe azokat. A Horatius szatíráiban megjelenő jogi szakkifejezések között vannak, melyek egyszerüen a római normák hangulatát közvetítik, ${ }^{21}$ míg mások kimondottan a humor forrásaként szolgáló helyzet leírásában kapnak szerepet. ${ }^{22}$ Cloud kiemeli,

${ }^{14}$ Lásd például a Trimalchio lakomájában szereplő gasztronómiai szakkifejezéseket (Petr. Sat. XXVI-LXXXVIII); a bevezetőben a retorikai terminusokat (Petr. Sat. I-V).

${ }^{15}$ Ahogy Rimell írja, hogy „the Satyricon is a theatrical, prismatic and highly metaphorical piece of writing in which viewing, imagining and picturing things are a rich, as well as unpredictable, mode of expression." Lásd V. Rimell: Petronius and the Anatomy of Fiction. Cambridge 2002. 8 sk.; Rimell: i. m. (10. jegyz.) 65. A Satyricon műfaji besorolásához lásd még Conte: i. m. (1. jegyz.) 459 skk.

16 J. D. Cloud: Satirists and the Law. In: S. H. Braund (ed.): Satire and Society in Ancient Rome. Exeter 1989. 50 sk.; Conte: i. m. (1. jegyz.) 469 sk.

17 Cloud: i. m. (16. jegyz.) 62 skk.

${ }^{18}$ Lásd Cloud: i. m. (16. jegyz.) 62 sk.; Conte: i. m. (1. jegyz.) 475 skk.

19 Iuvenalis néhány szatírájában kimondottan a város veszélyeit és romló erkölcseit hangsúlyozza. Lásd ehhez Gellérfi G.: Iuvenalis 3. szatírája és az interlocutor Umbricius irodalmi forrásai. AntTan 69 (2015) 38 skk.

${ }^{20}$ Lásd Cloud: i. m. (16. jegyz.) 62 sk.; Gellérfi: i. m. (19. jegyz.) 60 skk.

${ }^{21}$ Lásd Hor. Serm. I, 9; Vö. Cloud: i. m. (16. jegyz.) 63.

${ }^{22}$ Ilyen az örökségvadászoknak adott jó tanács is. Lásd Hor. Serm. II, 5. 
hogy kimondottan szimbolikus a szerepük, ezért az értelmezésükre a választ nem is a római jogban, ${ }^{23}$ hanem inkább a költői szándékban célszerű keresni. ${ }^{24}$

A három említett szatíraíró munkáiban a jognak inkább jelképes szerepe van, a jogi szakkifejezések az olvasó számára a jogi világ hangulatát idézik fel. Éppen ezért nem is azzal a pontossággal találkozunk, amelyet akár a jogtudósok munkáiban (iurisprudentia), akár a császári rendeletekben látunk. A jogi latin nyelv, hasonlóan az általa hordozott tartalomhoz, a joghoz, precizitást vár el. A szavak jelentésének nagy szerepet tulajdonító római jog megjelenése a szatírákban inkább iróniának tekinthető. Petronius a jogi problémák széles tárházát vonultatja fel a XII-XV. caput adásvételi jelenetében. Kérdés, hogy a jogi kifejezések és leírás milyen szerepet játszanak Petroniusnál. Vajon a jogi nyelvnek itt is csak jelképes a szerepe, vagy annál többről van szó? A következőkben a jelenetet az egyes jogi tényállások és a római jog vonatkozó szabályainak szemszögéből fogom bemutatni, rávilágítva a jogi szakkifejezések használatának petroniusi megoldására.

Amennyiben a tényállást a jogi minősítés szempontjából vizsgáljuk, első ránézésre nincs könnyü dolgunk. ${ }^{25}$ Négy nagyobb tényálláskörre bontható az eset:

1. a pallium eladása

2. a tunica visszaszerzésének módjai

3. a lelepleződés és a kialakuló vita

4. a sequestrum.

Valamennyi tényálláscsoport azonos helyszínen valósul meg, ahol elöször a pallium eladására, majd az eljárásra is sor kerül. A helyszínt Petronius lapidáris tömörséggel egy forumnak nevezi, amely nem a közismert Forum Romanum, hanem feltehetőleg egy városi forum valahol Dél-Itáliában. ${ }^{26}$ A forum tipikusan a jogszolgáltatás és az üzleti élet színterét jelenti a rómaiak számára, ahol nappal a jog és a rend uralkodott. Az este leszálltával (deficiente iam die) azonban a helyszín más funkciót kap, ${ }^{27}$ és kétes emberek és áruik tanyájává válik, ${ }^{28}$ ahol sántikáló becsületű árukon adnak túl (quarum fidem male ambulantem). A fidem male megfogalmazás a jogi szaknyelvben gyakori mala fidesre, azaz a „rosszhiszeműségre” utal. ${ }^{29}$ Tehát olyan árukról van szó, melyek valamilyen illegális úton jutottak az eladókhoz. A forum leírását a tego 'beborít' ige zárja, mely nem pusztán az áruk eredetére boruló homályt, hanem a készülő ügyletkötés homályát

${ }^{23}$ Lásd Cloud: i. m. (16. jegyz.) 51.

${ }^{24}$ Lásd Cloud: i. m. (16. jegyz.) 65 sk.

${ }_{25}$ A tényállás elemzéséhez használt latin szövegkiadás K. Müller (Hrsg.): Petronius, Satyricon Reliquiae. Leipzig $1995^{4}$.

${ }^{26}$ Horváth István Károly a fordításában kiegészítésképpen jelzi, hogy Itália egyik görög alapítású, dúsgazdag tengerparti városa, talán Nápoly vagy Puteoli lehet a történet első színtere. Lásd T. Petronius Arbiter: Satyricon. Fordította Horváth I. K. Budapest 1963. 2 skk.

27 Az est leszállta, a sötétség a homályosságot és titokzatosságot megteremtő metafora. Lásd Rimell: i. m. (10. jegyz.) 60.

${ }^{28}$ Vö. Hor. Serm. I, 6,113-114 (jósokról beszél az esti forumon).

${ }^{29}$ Ellentéte a szubjektív értelemben vett bona fides, amely 'jóhiszeműséget' jelent, lásd Földi A.: A jóhiszeműség és tisztesség elve. Intézménytörténeti vázlat a római jogtól napjainkig. Budapest 2001.9-10. 
is megjeleníti. Az esti forumnak jelképes a szerepe, amely a homályosítás egyik legfontosabb kelléke az egész jelenet során. ${ }^{30}$

Az adásvétel tárgya, az eladóinknál lévő pallium tökéletesen beleillik ebbe a helyzetbe, amelyet jelzője (raptum latrocinio pallium) még jobban konkretizál. A kommentárok sokat foglalkoznak azzal, hogy milyen úton került a pallium eladóinkhoz. A Schmeling-féle kommentár szerint több lehetőség is felmerül: 1) egy tolvajtól vették el a köpenyt; ${ }^{31}$ 2) sírról elemelt köpenyről van szó; ${ }^{32} 3$ ) a paraszt, aki megvenni készül a palliumot nem volt tolvaj, és csak véletlenül talált rá a tuniculára, elképzelhető, hogy Encolpiosék pedig a Priapus templomból lopták el a palliumot; 4) vagy éppen Lykurgostól. ${ }^{33}$ Mivel a Satyricon szövegének valószínűleg a nagyobb része elveszett, és a mű eleje sincs meg, amelyből kiderülhetne mi is történt, csak találgatni lehet a szövegben másutt szereplő különböző utalások alapján.

A találgatás helyett azonban érdemes a fennmaradt részek szavainak pontos - jogi, illetve nem jogi nyelvben bevett - jelentéséből kiindulni. A raptum latrocinio pallium esetében két jelző is szerepel a pallium mellett, és mindkettő a jogi latin szaknyelvben bevett szakszó. Mind a HS, ${ }^{34}$ mind az OLD alapján a raptum (<rapio 'elragad, elrabol') a jogi szaknyelvben kimondottan a rablásra utal (rapina), ${ }^{35}$ amely büncselekménynek (praetori delictumnak) minősültt. ${ }^{36}$ A rablás és a lopás közti választóvonalat az erőszak alkalmazása jelentette, mely a rablásnál tényállási elem. ${ }^{37} \mathrm{~A}$ rapio igét jogi értelemben használva pontosítható a tényállás, így itt nem egy lopott dologról van szó, hanem egy erőszakkal elragadott dologról. Ezt erősíti meg a latrocinium is, amely szintén 'rablást', ill. 'útonállást' jelent, ${ }^{38}$ és első ránézésre pleonazmusnak tekinthető. A jogi latin szaknyelvbe egy köznyelvi hatásra került be, de specializálódott a jelentése, és kimondottan rablást jelent. Kérdés, hogy Petroniusnál ez a szükebb értelemben vett jogi jelentés, vagy az OLD szerinti 3. jelentésnek megfelelő tág értelmet ('lopás') tulajdonítjuk-e a kifejezésnek.

${ }^{30}$ Rimell szerint a homályosítás egy trópus, mely végigvonul a Satyricon narratíváján. Lásd Rimell: i. m. (10. jegyz.) 93. Vö. G. Schmeling: A Commentary on the Satyrica of Petronius. Oxford 2011. 37.

31 Ezt megerősítik a később előforduló latrocinii suspicio (XV, 7) és a mendici spolium (XIII, 1) kitételek a szövegben. Lásd Schmeling: i. m. (30. jegyz.) 37. Vö. Sullivan: i. m. (4. jegyz.) 45 skk.

${ }^{32}$ Irodalmi párhuzamként említi Schmeling Photius Bibliotheca c. munkáját, melyben szintén a holtaknak szánt köpenyről van szó. Lásd Schmeling: i. m. (30. jegyz.) 37.

33 Schmeling: i. m. (30. jegyz.) 37. Vö. Conte: i. m. (1. jegyz.) 64 sk.

${ }^{34}$ E. Seckel: Heumanns Handlexikon zu den Quellen des römischen Recht. Jena $1907^{9}$, a továbbiakban HS

${ }^{35}$ Lásd HS rapere és rapina szócikkek; OLD rapio szócikk.

${ }^{36}$ A rablás alapján egy éven belül négyszeresre (quadruplum), egy éven túl egyszeresre (simplum) menő büntetőkereset járt, az actio vi bonorum raptorum. Lásd M. Kaser: Das römische Privatrecht I. München 1971-1975². 627; Földi-Hamza: i. m. (5. jegyz.) 570.

37 Mindazonáltal a római jog nem húzott éles határvonalat a két tényállás közé, amit az is bizonyít, hogy adott esetben a kétszeresre (duplum) menő actio furti nec manifesti is megindítható, amennyiben előbb került sor a lopás alapján történő perlésre. Ekkor a különbözet megtérítését lehetett perelni (Paul. Dig. XLVIII, 8,1). Lásd e szöveghez L. Vacca: Ricerche in tema di 'actio vi bonorum raptorum'. Milano 1972. 125-133.

${ }^{38}$ OLD ill. HS s. v. latrocinium 'útonállás' jelentésben hozza. 
A jogi szakkifejezések esetében már itt jelentkezik és a továbbiakban is figyelemre méltó a játék a szavak jogi, illetve nem jogi jelentése, valamint a jogi jelentésen belül is szűkebb, illetve tágabb értelme között. A latrocinium egyaránt szerepel a jogi és nem jogi latin nyelvben, és egyaránt van szükebb és tágabb jelentése. Itt tehát az értelmezés széles spektruma tág teret ad az olvasó fantáziájának. Jelen esetben a raptum viszont pontosítja ezt, és a 'rablás' értelmezése felé tereli az olvasót. Az adásvétel, amelynek tárgya esetünkben egy büncselekmény útján szerzett dolog, ${ }^{39}$ jól illik a helyszínen zajló rosszhiszemű és kétes ügyletek közé.

Petronius a következőkben az adásvételi (szerződési) jog szabályait két vonatkozásban emeli be a jelenetbe. Elsőként az említett pallium eladásával kapcsolatban, majd a tunica megvételére vonatkozóan. Az első esetben rablás útján szerzett, egyszersmind idegen dolog (res aliena $)^{40}$ eladásáról, míg a tunica esetében saját dolog (suae res emptio) megvételéről van szó. Kérdés, hogy a római jog miként viszonyult az adásvétel e két fajtájához.

A büncselekmény útján szerzett dolog a római jog szabályai szerint nem feltétlenül akadálya az adásvételi szerződés érvényességének. A főszabály szerint minden dolog elidegeníthető, ${ }^{41}$ kivéve azokat, melyeknél a természet vagy ius gentium, vagy a szokásjog ezt tiltja, és ezért érvénytelennek tartja az ilyen vételt. ${ }^{42} \mathrm{~A}$ jogtudósok műveiben szereplő tipikus példa, a lopott dolog adásvétele kapcsán az alábbi Paulus-fragmentum a következő három lehetőséget veszi számításba: ${ }^{43}$

Paul. Dig. XVIII 1, 34, 3 ad edictum:

Item si et emptor et venditor scit furtivum esse quod venit, a neutra parte obligatio contrahitur: ${ }^{43}$ si emptor solus scit, non obligabitur venditor nec tamen ex vendito quicquam consequitur, nisi ultro quod
Ugyanígy, ha a vevő és az eladó is tudott arról, hogy lopott az, amelyet eladnak, egyik fél javára sem keletkezik kötelem. ${ }^{44}$ Ha csak a vevő tudta, nem lesz érvényes a szerződés, és az eladó nem követelhet megtérítést az adásvétel alapján, ${ }^{45}$ csak

39 A lopott dolgok motívuma a comedia palliata alapján is jól ismert, elsősorban Plautus műveiből. Lásd N. Breitenstein: Petronius, Satyrica 1-15, Text, Übersetzung, Kommentar. Berlin - New York 2009. 157 skk.

40 Más tulajdonában lévő dolgot a római jogban mind adásvétel, mind ajándékozás útján érvényesen át lehetett ruházni, de a vevő elbirtoklásra szorult. Vö. Ulp. Dig. XVIII, 1, 28; Afr. Dig. XIX, 1, 30, 1. Lásd Siklósi I.: A nemlétező, érvénytelen és hatálytalan jogügyletek elméleti és dogmatikai kérdései a római jogban és a modern jogokban. Budapest 2014. 262 skk.; Földi-Hamza: i. m. (5. jegyz.) 511.

${ }^{41}$ Lásd Paul. Dig. XVIII, 1, 34, 1.

42 Siklósi: i. m. (40. jegyz.) 151, 524. j.

${ }^{43}$ Az érvénytelenséggel kapcsolatos, a római jog forrásaiban fellelhető latin megjelöléseket Siklósi Iván - igen terjedelmes felsorolásban - gyűjti össze, kiemelve, hogy értelmezésük nem egyértelmű, és a létezés - semmisség-megtámadhatóság hármasa, illetve az érvénytelenség és hatálytalanság közti finom distinkció sem érezhető maradéktalanul. Lásd Siklósi: i. m. (40. jegyz.) 148 skk.

${ }^{44}$ Az a neutra parte obligatio contrahitur kitétel fordításánál Siklósi Iván fordítását és értelmezését vettem alapul. Lásd Siklósi: i. m. (40. jegyz.) 151, 524. j.

${ }^{45}$ A non obligabitur is az érvénytelenséget jelölő szakkifejezés Lásd Siklósi: i. m. 154. 
convenerit praestet: quod si venditor scit, emptor ignoravit, utrinque obligatio contrahitur, et ita Pomponius quoque scribit. azt követelheti, amiről megállapodtak, hogy teljesíti; ha pedig csak az eladó tudta (azt, hogy lopott a dolog), a vevő nem tudta, mindkettejük számára keletkezik kötelem, és így írta Pomponius is. ${ }^{46}$

A lopott dolog (res furtiva) eladása tehát abban az esetben, ha a vevő is tudott a dolog lopott voltáról, semmisséget eredményez, ha viszont csak az eladó előtt volt ez ismeretes, akkor az adásvétel érvényes maradt. ${ }^{47}$ Megjegyzendő, hogy bármilyen idegen dolog vétele esetén a vevő mindenképpen elbirtoklásra szorult. ${ }^{48}$ Kérdés, hogy a jóhiszemüen szerzett, de lopott vagy erőszakkal elvett dolog (res vi possessae), így jelen esetben a pallium, elbirtokolható volt-e a római jogban. Ennek kapcsán fejti ki Gaius a következő szabályt: ${ }^{49}$

Iust. Inst. II 6, 1: Sed aliquando etiamsi maxime quis bona fide rem possederit, non tamen illi usucapio ullo tempore procedit, veluti si quis liberum hominem vel rem sacram vel religiosam vel servum fugitivum possideat.

Iust. Inst. II 6, 2. Furtivae quoque res et quae vi possessae sunt, nec ... usucapi possunt: nam furtivarum rerum lex duodecim tabularum et lex Atinia inhibet usucapionem, vi possessarum lex Iulia et Plautia.
Némelykor azonban, még ha valaki teljes jóhiszemüséggel birtokolt bármilyen hosszú ideig egy idegen dolgot, nem következik be nála elbirtoklás. Például, ha valaki akár szabad embert, akár szent dolgot, akár temetkezési helyet, ${ }^{50}$ akár szökött rabszolgát birtokolna.

Sem a lopott dolgokat, sem azokat, amelyeket erőszakkal birtokolnak, nem lehet elbirtokolni... Ugyanis a lopott dolog elbirtoklását a XII táblás törvény és a lex Atinia tiltja, ${ }^{51}$ az erőszakkal szerzett dolgokét pedig a lex Iulia és Plautia. ${ }^{52}$

${ }^{46}$ Jelen fordítás a szerző saját fordítása.

47 Földi-Hamza: i. m. (5. jegyz.) 511.

48 Siklósi: i. m. (40. jegyz.) 263 skk.

49 Vö. Gai. Inst. II, 45.

50 A res sacra 'szent dolog' alatt a rómaiak az égi isteneknek (dis superis) szentelt dolgokat értették, míg a res religiosa 'temetkezési hely' alatt az alvilági istenekre (dis Manibus) bízott dolgok csoportját. Lásd. FöldiHamza: i. m. (5. jegyz.) 277 skk.

${ }^{51}$ XII táblás törvény VIII, 17: Furtivam (rem) lex XII tab. usu capi prohibet - A XII táblás törvény tiltja, hogy lopott (dolgot) elbirtokoljanak. A szakirodalomban vitatott kérdés, hogy ezt a tilalmat melyik törvény tette általánossá, már a XII táblás törvény vagy csak a lex Atinia Kr. e. 200 körül. Lásd H. Hitzig: s. v. furtum. PWRE VII (1910) 385-386; a kérdéshez részletesen Siklósi: i. m. (40. jegyz.) 263, 983. j.; H. Ankum: L’application de la loi Atinia aux cas de « furtum pignoris » et de «furtum fiduciae ». In: G. Constable - M. Rouche (eds.): Auctoritas. Mélanges offerts à Olivier Guillot. Paris 2006. 18 skk.

${ }_{52}$ Lex Iulia et Plautia de usucapione rerum vi possessarum: (Gai. Inst. II, 45; Iul. Dig. XLI, 3, 33, 2) tulajdonképpen két külön törvény (lex Iulia és lex Plautia de vi), melyek szerint erőszakosan elvett dolgok nem válhattak tulajdonná usucapio által. Lásd Ankum: i. m. (51. jegyz.) 18 skk. 
A lopott vagy erőszakkal elvett dolog megszerzése tehát elbirtoklás útján nem lehetséges Gaius szerint. ${ }^{53} \mathrm{Ez}$ a tilalom nem magát a rosszhiszemű szerzőt érinti, hanem éppen a jóhiszemű szerzőket. ${ }^{54}$ Ugyanis a rablás útján, vagyis az erőszakkal szerzett birtok nem eredményez elbirtoklást, mivel az egyszeri hibás szerzés a későbbi birtokosoknak is árt, még ha megfelelő jogcím (iusta causa) alapján birtokolnak is. ${ }^{55}$ Ezt a hibát (a dolog elbirtoklásra való alkalmatlanságát) úgy lehetett orvosolni, ha a res inhabilis valamiképpen visszakerült a tulajdonoshoz, vagy annak örököséhez, ${ }^{56}$ és ezáltal újra elbirtokolhatóvá vált. ${ }^{57}$

Idegen dolog adásvételének a római jogban a források tanúsága szerint négy lehetséges kimenetele van:

1. az eladó és a vevő is tud a dolog lopott voltáról: az adásvétel kötelmi és dologi szempontból egyaránt semmis;

2. csak a vevő tud a dolog lopott voltáról: a szerződés érvénytelen, és a vevő nem birtokolhat el;

3. csak az eladó tud a dolog lopott voltáról: a szerződés érvényes, dologi jogi szempontból viszont a vevő nem birtokolhat el;

4. egyikük sem tud a dolog lopott voltáról: a szerződés érvényes, és a vevő elbirtokolhat.

A jelenetben szereplő pallium adásvételénél ezek közül a harmadik eset valósulna meg. Petronius azonban még egy csavart tesz a történetbe, hiszen a vevő nem más, mint a pallium tulajdonosa, akinek eladóink idegen dologként készülnek eladni saját köpenyét. ${ }^{58}$ Petronius ezzel a fordulattal a feje tetejére állítja a tényállást, hiszen olyan idegen dologról (res aliena) beszél, amelyről kiderül, hogy sajátja (res sua). Az adásvételi szabályok egy másik csoportját alkalmazza, hiszen a saját dolog vétele (emptio rei suae) más tekintet alá esik a római jogban: ${ }^{59}$

Pomp. Dig. XVIII 1, 16 pr. ad Sabinum: Suae rei emptio non valet, sive sciens sive ignorans emi. Sed si ignorans emi, quod solvero repetere potero, quia nulla obligatio fuit. ${ }^{59}$
Saját dolog megvétele nem érvényes, akár tudva, akár nem tudva vettem. De ha nem tudva vettem, amit teljesítek, azt vissza fogom tudni követelni, mivel semmilyen kötelem nem volt.

53 A különböző nézetekhez lásd részletesen Siklósi: i. m. (40. jegyz.) 263, 983. j.

54 Vö. Gai. Inst. II, 50.

55 Vö. Gai. Inst. II, 49.

56 Vö. Venul. Dig. XLVII, 8, 6. Lásd Ankum: i. m. (51. jegyz.) 20 skk.

${ }^{57}$ Lásd Siklósi: i. m. (40. jegyz.) 263 skk.; Ankum: i. m. (51. jegyz.) 20 skk.

${ }^{58}$ Itt is felmerül a saját dolog adásvételének kérdése. Lásd alább a „Mihi placet emere, quamvis nostrum sit." mondat elemzésénél.

59 Vö. Paul. Dig. XVII, 1, 22, 3; Pap. Dig. XIII, 7, 40 pr.; Iav. Dig. XLI, 3, 21. A forrásokhoz lásd részletesen Siklósi: i. m. (40. jegyz.) 150, 521. j. 
Tehát ellentétben a rablás útján szerzett dolog vételével, itt már maga a szerződés sem lesz érvényes. ${ }^{60}$ Petronius nemcsak a szakkifejezésekkel, de a római jogi szabályokkal is játszik. A történetben az egyes fordulatok az egyes jogi szituációk és szabályozás változását is jelentik, amitől kellően dinamikus lesz a jelenet.

A következő, XIII. és XIV. caputokban egy újabb jogterület jelenik meg a szatírában, az eljárásjog. A római eljárásjog az egyes szatíraíróknál ritka, hosszabb jelenettel Horatius Sermones első kötetében találkozunk, az Ibam forte via sacra, sicut meus est mos kezdetű szatírában. ${ }^{61}$ Petroniusnál egy hosszabb és sokkal világosabb jelenet ${ }^{62}$ bontakozik ki, amikor eladóink a vevőnél megpillantják a tuniculát is, amelyben az arany rejtőzik, melyet korábban elvesztettek. Petronius nem pusztán egy-egy szóval utal az eljárásra, hanem konkrét jogintézményeket és eljáró hatóságokat is megemlít.

Ez a rész hemzseg a jogi szakkifejezésektől, és főleg az igényérvényesítés lehetőségeit veszi számba, ahogy Ascyltos azon töpreng, milyen címen is kellene visszaszerezni a tunicát: „Quid ergo facimus, aut quo iure rem nostram vindicamus?” (XIII 3). ${ }^{63}$ A vindico ige jelen esetben nem szűkebb jogi értelmében szerepel itt, mely a tulajdonvédelmi perre utalna, ${ }^{64}$ hanem véleményem szerint a HS szerinti 4 . jelentése alapján adsero értelemben 'valamilyen jogot (perben) érvényesít' jelentéssel. A quo iure a visszakövetelésre utal, a iure a quo-hoz tartozik, amely nem feltétlenül jogi jelentésű (milyen jogi úton), hanem egyszerűen 'hogyan, milyen úton-módon' értelemben szerepel. Ez megfelel annak, hogy az igényérvényesítésről máshogy vélekednek a szereplők. Míg Encolpios a jogvita irányába terelné a kérdést (iure civili dimicandum esse), ${ }^{65}$ addig Ascyltos szán-

${ }^{60}$ Jelen esetben tehát vagy érvénytelen (non valet / nulla emptio est), vagy nem létező (consistere non possit) szerződésről van szó. Siklósi Di Paola nézetéből kiindulva jegyzi meg, hogy nincs értelme jelen esetben a kettő közti éles különbségtételnek. Lásd Siklósi: i. m. (40. jegyz.) 112 sk. Mégis kivételesen érvényes lehet a saját dolog megvétele, lásd Paul. Dig. XVIII, 1, 34, 4; vö. Földi-Hamza: i. m. (5. jegyz.) 514, 2. j.

61 Lásd. Hor. Serm. I, 9.

${ }^{62}$ A horatiusi szatíránál sok vitatott kérdés van, így például az eljárás szakasza, a jogi szakkifejezések különös használata, vagy a jogi tanácsadás mibenléte. Lásd Cloud: i. m. (16. jegyz.) 67 skk.

${ }^{63}$ Miután Ascyltos megbizonyosodott a tunicába rejtett arany meglétéről, egyenesen úgy teszi fel a kérdést, mintha tapasztalt jogtudós lenne. Lásd Breitenstein: i. m. (39. jegyz.) 160 sk.

${ }^{64}$ A vindico jogi szövegekben, legszűkebb értelemben, a rei vindicatiót jelenti, azaz a civiljogi tulajdonos keresetét (vö. Földi-Hamza: i. m. [5. jegyz.] 346 skk., Kaser: i. m. [36. jegyz.] 433 skk.), szűkebb értelemben pedig valamennyi dologi jogi igényt érvényesítő keresetet (in rem actio). Tág értelemben az adsero szinonimája. (vö. HS, OLD).

65 A ius civilére történő utalás igen gyakran a régi merev civiljog szabályait jelentette szemben a Kr. e. III. századtól kialakuló praetori jog méltányosabb szabályaival. Schmeling szerint nem szigorúan a ius civile, hanem a ius praetorium normáiról van szó. A principátus jogrendszerének korára - amelyet feltételezünk a mü cselekményénél - már elhalványul ez a szembenállás, a két jog összeolvadása figyelhető meg. Ekkor a ius civile, általánosabban a ius, a jogtudósok nézeteit jelenti (iurisprudentia), szemben a lexnek nevezett császári rendeletekkel (constitutio). Később a császárkorban pedig egyenesen magánjog (ius privatum) értelemben használták. Itt véleményem szerint fordítható egyszerüen jognak vagy civiljognak is. Lásd Földi-Hamza: i. m. (5. jegyz.) 51 skk.; Kaser: i. m. (36. jegyz.) 207 skk. 
déka az, hogy ne perben érvényesítsék jogukat, hanem egyszerüen vásárolják vissza a tunicát. (Mihi plane placet emere, quamvis nostrum sit. XIV 1). ${ }^{66}$

Encolpios további utalásokat is tesz a jogi eljárással összefüggésben: ut si nollet alienam rem domino reddere, ad interdictum venirent (XIV 4). A mellékmondat erős túlzás, hiszen rosszhiszemü birtokosként tulajdonosnak vallani magukat „enyhe arcátlanság", mely a szatírák megszokott stílusát tükrözi. Az interdictum a legtágabb értelemben parancsot, valamilyen tilalmat jelent, ${ }^{67}$ a jogi szférában kimondottan praetori parancsot, jogsegélyt, ${ }^{68}$ szűkebb értelemben egy (birtokvédelmi) jogsegélyre utal. ${ }^{69}$ Véleményem szerint Petronius nem csupán jelképesen használja a szakkifejezést, hanem a konkrét birtokvédelmi eszközre utal vele.

A klasszikus jog szabályai szerint ingó dolog esetén a rendelkezésre álló interdictum, az ún. interdictum utrubi, amely a birtok megtartását célozza. ${ }^{70} \mathrm{Az}$ interdictum az Otto Lenel-féle rekonstrukció alapján a következőképpen szólt:

\section{UTRUBI HIC HOMO, QUO DE AGITUR, MAIORE PARTE HUIUSCE ANNI NEC VI NEC CLAM NEC PRECARIO AB ALTERO FUIT, QUO MINUS IS EUM DUCAT, VIM FIERI VETO. ${ }^{71}$}

Tehát a praetor az utrubi alapján kijelentette, hogy „Megtiltom ${ }^{72}$ erőszak alkalmazását abban a vonatkozásban, hogy ezt a rabszolgát, akiről a per folyik, akinél ennek az évnek a nagyobb részében erőszak nélkül (nec vi), nem alattomban (nec clam), és nem a szívességi használatba adott dolog visszakövetelése ellenére (nec precario) volt, az el ne vezethesse." 73

${ }^{66}$ Ez utóbbi ismét visszakanyarodás az adásvétel szabályaihoz, amely a saját dolog vételének szabályait juttatja a jogban járatos olvasó eszébe.

${ }^{67}$ Az OLD szerinti 1. jelentés.

${ }^{68}$ A HS szerinti 1. és 2. jelentés, hasonlóan az OLD szerinti 2. jelentéshez.

${ }^{69}$ Az interdictum eredendően praetori tilalmat jelentett (vö. HS szerinti 1. jelentés), majd ebből alakult ki az a peren kívüli jogsegély, mely az egyik fél kérelmére kibocsátott végzés, amely lehet exhibitorium, prohibitorium vagy restitutorium. A birtokvédelem körében a római jogban interdiktális védelemmel találkozunk, azaz a birtok tényét nem peres eljárás (actio) védte. Lásd Földi-Hamza: i. m. (5. jegyz.) 313 skk., M. Kaser K. Hackl: Das römische Zivilprozessrecht. München $1996^{2} .411$ skk.

${ }^{70}$ Lásd L. Labruna: 'Vim fieri veto'. Alle radici di una ideologia. Napoli 1971. 91 skk.; Kaser-Hackl: i. m.(69. jegyz.) 411 skk.; Kaser: i. m. (36. jegyz.) 387 skk.; Földi-Hamza: i. m. (5. jegyz.) 314 skk.

${ }^{71}$ Lenel a következő források alapján rekonstruálja az interdictum szövegét: Ulp. Dig. XLIII, 31, 1 pr.; Gai. Inst. IV, 160. Vö.: O. Lenel: Das „Edictum perpetuum”. Leipzig 1927³. 391 sk. Lásd továbbá Labruna: i. m. (70. jegyz.) 93 sk.; Kaser-Hackl: i. m. (69. jegyz.) 417; D. Schanbacher: Interdictum. DNP V. 1032-1034.

72 A vim fieri veto szavak alkalmazása az interdictum prohibitoriumra jellemző fogalmazás, mely az interdicere legszűkebb értelmét leginkább visszaadja. Lásd Kaser-Hackl: i. m. (69. jegyz.) 413 skk.; Labruna: i. m. (70. jegyz.) $123 \mathrm{skk}$.

${ }^{73}$ Brósz Róbert fordításának felhasználásával. Lásd Brósz R. (ford.): Gaius Institutiói - Négy kommentár. Budapest 1990. 184 sk. 
Az utrubi szabályai szerint annak a birtokosnak előnyösebb a helyzete, aki az ingó dolgot az elmúlt egy év alatt hosszabb ideig ${ }^{74}$ birtokolta hibátlanul. ${ }^{75} \mathrm{Ez}$ az interdictum a dolog megtartására irányul, azonban ha nem a megfelelő birtokosnál van, akkor visszaszerző hatályúvá válik, és a megfelelő birtokosnak kell kiadni. ${ }^{76} \mathrm{Ha}$ arra gondolunk, hogy eladóink miféle köpenyen igyekeznek túladni, akkor rögtön érthetővé válik, hogy egy ilyen feltételekkel meghatározott interdictum és a törvényes út helyett Ascyltos inkább a kerülőutat pártolja. Érvelésében viszont nem erre hivatkozik, ${ }^{77}$ hanem sokkal általánosabb érveket vonultat fel a jogi út kikerülésére.

Az egyik ezek közül, hogy idegenek, és ezért senki sem adna hitelt nekik („Quis” aiebat „hoc loco nos novit, aut quis habebit dicentibus fidem?” XIII, 4), mellyel az esetleges iusiurandum, valamint a testimonium esetén jelentkező hátrányukra utal. ${ }^{78}$ Úgyszintén megjegyzi, hogy in ambiguam litem descendere, vagyis ha pert (lis) indítanának, annak bizonytalan lenne a kimenetele. Végül döntő érve a rendszer korruptsága. Itt - talán a mondanivaló további fokozására - a prózai szöveg versbe vált át, ${ }^{79}$ melyet igen találóan quid faciant leges kezdettel indít, ${ }^{80}$ feltéve a kérdést, hogy mit tehetnek még a törvények ott, ${ }^{81}$ ahol pénzért bármi megvehető (non nunquam nummis vendere verba solent) és ahol a iudicium semmi más, csak kiterített áru (iudicium nihil est, nisi publica merces).

Petronius itt a meglehetősen bizonytalan iudicium kifejezést használja, amely a jogi latin nyelvben elég széles körü jelentéssel bír. Gyakorlatilag minden határozatot, amely a iudextől (esküdtbíró) származott, iudiciumnak neveznek, ugyanakkor a rendes peres eljárásban a jogvita szakaszaival kapcsolatos kifejezésekben a per praetor előtt

${ }^{74}$ Erre a határidőre tekintettel elődeinek a birtoklása is számításba jön. Lásd Kaser: i. m. (36. jegyz.) 387 skk.; Földi-Hamza: i. m. (5. jegyz.) 314 skk.

75 Vö. Gai. Inst. IV, 150; Ulp. Dig. XLIII, 31, 1, 1. Lásd még Lenel: i. m. (71. jegyz.) 391 sk.; Kaser: i. m. (36. jegyz.) $387 \mathrm{skk}$.

${ }^{76}$ Kaser: i. m. (36. jegyz.) 396 skk.; Földi-Hamza: i. m. (5. jegyz.) 314 skk.

77 Ascyltos ezen a ponton érveléséhez az elégia formáját választja (Petr. Sat. XIV, 2), amely kellően rugalmas a költői mondanivaló megjelenítéséhez, a konkrét esetben pedig arra, hogy Encolpiost eltérítse szándékától. Lásd ehhez részletesen N. W. Slater: Reading Petronius. Baltimore - London 1990. 163 skk.

${ }^{78}$ A vadimoniummal, testimoniummal kapcsolatos jogi szabályozás más szatíraíróknál is kedvelt téma, így Iuvenalisnál és Horatiusnál is. Vö. Verboven: i. m. (2. jegyz.) 126 skk.

79 A petroniusi szatíra műfajára jellemző sajátosság. Lásd Conte: i. m. (1. jegyz.) 459 sk.

${ }^{80}$ A quid faciant leges kezdetet érdemes összevetni egy hasonló, Iuvenalisnál szereplő hellyel, nevezetesen a quid Romae faciam? kezdetű sorokkal (Iuv. 3, 41-47), továbbá a Martialisnál szereplő Quid faciam? felütéssel (Mart. III, 38, 13-14). Mindhárom szöveghely fő motívuma a tisztességtelenség, becstelenség, hazugság. Ascyltos érvelése párhuzamba állítható mind a iuvenalisi, mind a martialisi hellyel, melyek tanulsága, hogy csak a szerencsének köszönhető, ha valaki tisztességesen tud élni. A iuvenalisi és martialisi hely közötti összefüggést részletesen lásd Gellérfi: i. m. (19. jegyz.) 60 skk.

${ }^{81}$ A lex jelentése mind a HS, mind az OLD alapján igen szerteágazó lehet, de itt úgy vélem, hogy a legáltalánosabb (HS és OLD szerinti 1.) jelentésében ('törvény') szerepel. Vö. ThLL usu maxime Romano: leges publicae, praesertim rogatae sive (sub regibus, Caesaribus et apud externas gentes) quomodocumque latae. 
zajló, ún. in iure szakaszára is utal. ${ }^{82}$ Az előtte nem sokkal szereplő perre utaló lis kifejezés után egyaránt jelentheti az eljárást illetve az ítéletet, egyszerre utalva a praetor, ill. a iudex korruptságára. A publica merces 'kiterített áru' fordításban adható vissza legjobban. ${ }^{83} \mathrm{Ez}$ az értelmi fordítás ugyanakkor nem áll összhangban a latin megfelelővel a hozzátartozó publica miatt. Itt ugyanis nem a merx (mercis) 'áru' főnévről van szó, hanem a merces (mercedis) 'bérleti díj, kamat, jövedelem' fönévről. ${ }^{84}$ A merces (mercedis) OLD szerinti 5. jelentése ugyanakkor többek között erre a konkrét forráshelyre hivatkozással épp az eladásra kínált árut jelenti. Petronius itt a jogi kifejezéseket konkrét értelemben alkalmazza, kihasználva azok hétköznapi és jogi értelmének egybecsengését. A szatíra hangvételének megfelelően, Ascyltos korrupcióra történő hivatkozása költői túlzás. ${ }^{85}$

A kerülőútnak is megvannak azonban a buktatói, és eladóink hamar lelepleződnek. A XV. caputba átlépve, a kialakuló vita során előbb az alkuszokat (cociones), majd az eljáró hatóságokat hívja a helyszínre, mely utóbbira az advocati tamen [iam poenae] nocturni kitétel utal (XV 2). Az este homályában nem tudják eldönteni az ügyet, ezért kerül sor a letétbe helyezésre, hogy másnapra maradjon is valami a pertárgyból. Petronius az eljárási szabályok mellett a letét, így különösen a sequestrum, valamint a felmutatási kötelem (ad exhibendum actio) szabályait is beemeli a jelenetbe. Bár az advocati nocturni homályos megjelölés, a letétbe helyezésnél világos és egyértelmű a szakkifejezések használata.

Az advocati nocturni megnevezés alapján nem derül ki pontosan, hogy kikről van szó. Az advocati jelentése meglehetősen széles, az OLD alapján szűkebb, jogi értelemben 'valaki, aki támogatja a felet egy peres eljárás során', azaz ügyvéd, esetleg jogi képviselö, vagy vindex ${ }^{86}$, illetve 'támogató, közvetítő, tanú ${ }^{87}$ Schmeling szerint az advocati itt legtágabb értelmében - a szó eredeti jelentésénél maradva - annyit jelent, hogy 'oda-

82 Így pl. ante iudicium = ante litem contestatam, azaz a litis contestatio elötti, in iure szakasz (vö. Ulp. Dig. XXI, 1, 25, 8); ad iudicium non adesse (vö. Ulp. Dig. XLII, 8, 3, 1). Emellett pedig az actio (kereset) szinonimájaként alkalmazza a iustinianusi törvényalkotás, így a iudicio agere $\mathrm{v}$. iudicio petere kifejezésekben (Gai. Inst. III, 180-181), valamint leginkább a iudicium in factum datur (= actio in factum datur, pl. Ulp. Dig. II, $7,5,1$ ), dato in rem iudicio (= dato in rem actione, pl. Ulp. Dig. IV, 4, 13, 1) kifejezésekben (lásd HS s. v. iudicium).

${ }^{83}$ A Horváth-féle műfordítás szerint „az ítélet nem más, mint üzleti áru”, de a publicát nem fordítja. Lásd Horváth I. K.: i. m. (26. jegyz.) 8.

${ }^{84}$ A két említett szó a merx és merces az OLD illetve a HS szerinti jelentése a köznyelvben és a jogi szaknyelvben megegyezik. Lásd OLD-HS s. v. merx és OLD-HS s. v. merces.

${ }^{85}$ A korrupcióhoz lásd Verboven: i. m. (2. jegyz.) 126 skk.; Conte: i. m. (1. jegyz.) 476 skk.

${ }^{86}$ Az advocatus OLD szerinti 1. jelentése, amely a HS által hozott jelentéssel ('ügyvéd, jogi képviselö') megegyezik. A vindex a HS szerinti 1. jelentés alapján az a személy, aki az in ius vocatio (idézés) alkalmával megjelent a praetor előtt a felperes helyett. Vö. qui in ius vocatus neque venerit (ierit?) neque vindicem dederit (Gai. Inst. IV, 46); Hor. Serm. I, 9 szatírájának is kedvelt témája.

${ }^{87}$ Lásd az OLD szerinti 2. jelentést. Az advocatus szerepel egy későbbi epizódban is, ahol ügyvéd, támogató értelemben fordítható: periclitantium advocatus (Petr. Sat. CX, 6), azaz a 'bajbajutottak ügyvédje' Horváth találó müfordítása alapján (lásd Horváth I. K.: i. m. [26. jegyz.] 65.). Az epizódban egy egyezséget segít megkötni, Encolpios védelmére kelve. Ugyanakkor a palliumról szóló epizódban az 'ügyvéd' fordítás biztosan nem helyénvaló, hiszen a kontextusból és a szóhasználatból kiderül, hogy itt magistratusokra kell gondolnunk. 
hívott' (<advoco), ill. a 'tanúul hívott' jelentést is hozzáteszi. ${ }^{88} \mathrm{Az}$ advocati mellett szereplő nocturni esetében az OLD szerinti 1 . jelentés kapcsán említhető, ${ }^{89}$ hogy bizonyos hivatalnokokat illettek ezzel a megnevezéssel, akik éjszaka őrködtek Róma biztonsága felett. Mind a HS, mind az OLD említi egy konkrét Digesta helyre hivatkozva:

Paul. Dig. 1, 15, 1 de officio praefecti vigilum:

Apud vetustiores incendiis arcendis triumviri praeerant, qui ab eo, quod excubias agebant nocturni dicti sunt: interveniebant nonnumquam et aediles et tribuni plebis.
A régieknél a tűzvészek megelőzéséért felelős három hivatalnokot (triumviri), akiket arról, hogy éberen őrködtek, éjjelinek (nocturni) nevezték: néha az aedilisek és tribunus plebisek is ellátták ezt (a feladatot).

A praefectus vigilum ${ }^{90}$ testületéhez tartozó, általában lovagrendi hivatalnokok látták el a rendőri feladatokat Rómában. Kommentárjában Schmeling - Mommsen és Domaszewski alapján - a tresviri capitalest említi, ${ }^{91}$ hozzátéve, hogy azok hatásköre csak Rómára terjedt ki, de feltételezhetően hasonló magistratusok jártak el a kisebb városokban is. ${ }^{92}$ Ugyanakkor a principátus korára egyrészt a tresviri capitales feladatai fokozatosan beolvadtak a praefectus vigilum illetve a praefectus urbi hatáskörébe ${ }^{93}$ másrészt a praefectus vigilum hatásköre, ${ }^{94}$ amely kezdetben csak Rómára, később Itáliára is kiterjedt, ${ }^{95}$ és ők látták el a jogszolgáltatással kapcsolatos ${ }^{96}$ feladatokat az itáliai városokban müködő egyéb, kisebb hivatalnokok mellett. ${ }^{97}$

${ }^{88}$ Az advoco ige OLD szerinti 1. jelentése. Vö. Schmeling: i. m. (30. jegyz.) 204.

89 OLD s. v. nocturnus vö. Item P. Villius triumvir nocturnus a P. Aquilio tribuno pl. accusatus populi iudicio concidit, quia vigilias neglegentius circumierat (V. Max. Fact. et Dict. Mem. VIII, 1 damn. 6); Paul. Dig. I, 15, 1 (melyet a HS s. v. nocturnus is hoz); tribunatu ante gesto triumviratibusque, nocturno altero coloniae deducendae (Liv. Ab Urbe Cond. IX, 46, 1-3).

90 Vö. Pomp. Dig. I, 2, 2, 30. Lásd C. Cascione: 'Tresviri capitales': storia di una magistratura minore. Napoli 1999. 13 skk.

91 A kontextus egyértelművé teszi, hogy követelik a letétbe helyezést. Erre legfeljebb egy hivatalnoknak lehet hatásköre. Így sokkal valószínűbb, hogy itt magistratusokról van szó. Lásd L. de Libero - D. O. A. Klose: Dietrich. Tresviri. DNP XII/1 785-786; Havas L. - Németh Gy. - Szabó E.: Tresviri capitales. Római történeti kézikönyv. Budapest 2001.

92 Lásd Schmeling: i. m. (30. jegyz.) 205 sk. Vö. Cascione: i. m. (90. jegyz.) 22 skk.

93 Lásd Cascione: i. m. (90. jegyz.) 64.; Földi-Hamza: i. m. (5. jegyz.) 47, 3. j.

${ }^{94}$ A császárkorra letisztult szabályozás szerint a praefectus vigilum hatásköre nem terjedt ki az eset elbírálására, hanem a gyanút, illetve a megtörtént esetet kötelesek voltak jelenteni az általuk felügyelt városra illetékes bírónak, hogy az döntést hozzon az ügyben. Lásd Cod. Iust. I, 43,1 [a. 385 - 389]. Vö. W. Eck: Praefectus vigilum. DNP X. 246.

95 Földi-Hamza: i. m. (5. jegyz.) 48 skk.

96 Vö. Hitzig: i. m. (51. jegyz.) 399.

97 Erről tanúskodnak a feliratokon szereplő „Duumviri I. D.” (iuri dicundo), „Quattuorviri I. D.” megnevezések. Lásd W. Smith: A Dictionary of Greek and Roman Antiquities. London 1875. 983 skk. A municipiumokban eljáró magistratusoknak kevesebb intézkedésre terjedt ki a jogköre, így Kaser megjegyzi, hogy pl. missio in possessionem kibocsátására nem volt jogkörük, ugyanakkor interdictumot adhattak ki. Kaser-Hackl: i. m. (69. jegyz.) $177 \mathrm{skk}$. 
A fentiek alapján az advocati nocturni értelmezésénél két megoldás lehetséges. Egyfelől elképzelhető, hogy ügyvédekről van szó, akik csak hasznot akarnak húzni a palliumból (volebant pallium lucri facere). A másik lehetőség, hogy hivatalnokokról lehet szó, akik a lopás gyanúja miatt (latrocinii suspicio XIII, 3) követelik mind a pallium, mind a tunica letétbe helyezését (flagitabant uti apud se utraque deponerentur ac postero die iudex querellam inspiceret fordulat XIII, 2). Ha az elsőt fogadjuk el, akkor a iuvenalisi téves jogi szóhasználathoz hasonlóan értelmezhetjük a petroniusi jelenetet, amely a jogi eljárás karikatúráját jelenti. Ugyanakkor úgy vélem, hogy az advocati nocturni esetében alighanem odahívott magistratusokra kell gondolnunk. ${ }^{98} \mathrm{Ez}$ az olvasat a szituáció szempontjából inkább helytálló, ha arra gondolunk, hogy egyrészt Ascyltos korruptnak tartja az eljárást, amit mi sem példáz jobban, mint a magistratusok és az alkuszok gazdagodási szándéka. ${ }^{99}$ Másrészt az ügyvédek aligha követelhették a letétbe helyezést a másnapi eljárásra való tekintettel.

A iam poenae/pene fordulat szintén vitatott, a kiadások egy részében, így Teubner-féle szövegkiadásban is iam pene szerepel, ${ }^{100}$ de $c r u x$ jelzi, hogy a szöveg ezen a ponton menthetetlen. ${ }^{101} \mathrm{~A}$ Bücheler alapján elfogadott olvasat iam poenaet ír, mely a bírságolási célra utalna. Ez az eljáró hivatalnokok hatáskörét tekintve szintén elképzelhető. Schmeling az importune olvasatot fogadja el Nisbet alapján 'hirtelen, nem megfelelö, nem alkalmas időben' értelemben, amely a hivatalnokok éjszakai felbukkanására utal. ${ }^{102}$ Az egyes olvasatok vitatottak, jelen esetben értelmileg - a lopás gyanújával és a másnapi eljárással összefüggésben a iam poena olvasat illene legjobban a szövegbe, de bizonytalan olvasatokra tekintettel csak feltételezésről beszélhetünk.

A sequestrummal kapcsolatban Petronius pontosan alkalmazza az erre vonatkozó szabályokat. A sequestrum speciális fajtája a letétnek, melynek lényege, hogy a felek vita esetén egy harmadik személynek adják a dolgot, hogy őrizze, amíg eldöntik, kit illet va-

\footnotetext{
${ }_{98}$ Schmeling is magistratusokat feltételez, hozzáteszi viszont, hogy azok sequesterként lépnek fel, de az egyik cocio elorozza a ruhát, hogy majd másnap ő mutassa be. A magam részéről viszont úgy gondolom, hogy a sequesterek a kontextusra tekintettel is az alkuszok közül kerültek ki, és nem a magistratusok közül (lásd Schmeling: i. m. [30. jegyz.] 42). Emellett érdemes megemlíteni, hogy az itt szereplő bemutatási kötelezettség valószínűleg egy interdictum exhibitoria lehetett, vagy az actio ad exhibendum (felmutatási kötelezettségen alapuló kereset, amely egyébként a civilis possessor sequestert is terhelte). Ehhez lásd Kaser: i. m. (36. jegyz.) 434 skk.; Földi-Hamza: i. m. (5. jegyz.) 581.

99 Vö. Schmeling: i. m. (30. jegyz.) 42.

100 A iam pene, amely pontosabban iam paene lenne, pedig 'már csaknem' jelentéssel fordítható, mely a Horváth István-féle műfordításban is szerepel („a csaknem éjjel odahívott ügyvédek”, Horváth: i. m. [26. jegyz.] 8).

101 Lásd Müller: i. m. (25. jegyz.) 11.

102 Lásd Schmeling: i. m. (30. jegyz.) 42.
} 
lójában. A letétbe helyezést az advocati nocturni rendeli el, ${ }^{103}$ melyre a szövegben több jogi szakkifejezés is utal, így a flagito, ${ }^{104}$ depono, ${ }^{105}$ querela, ${ }^{106}$ iudex. ${ }^{107}$

A sequester (vitás dolog letéteményese) a nyertes félnek adja ki a dolgot, ${ }^{108}$ és a római jog szabályai szerint ún. civilis possessor ${ }^{109}$ Erre tekintettel követelhető tőle a dolog felmutatása. Az egyik alkusz, aki nagyon ajánlkozik sequesternek meg is ígéri, hogy másnap bemutatja a dolgot (pallium exhibiturum XV, 4). Az exhibendum kifejezés még egyszer szerepel a XV. caput végén exhibendum postularemus (XV, 7), mely a HS alapján vagy egy interdictum exhibitoriára, vagy az actio ad exhibendum, felmutatási kötelemre utal. ${ }^{110}$

A helyzet paródiája, hogy bár a sequestrum egyértelműen a bizonyíték másnapi eljárásig való megőrzését szolgálja, ${ }^{111}$ az egyik alkusz, aki máskor is a peres ügyekbe szokott avatkozni, ${ }^{112}$ szeretné elorozni a letétbe helyezett dolgokat. A letétbe helyezés azonban elmarad, mivel a paraszt abbéli felháborodásában, hogy egy rongydarab jogi helyzetét vitatják eladóink a palliummal szemben, Ascyltos arcába vágja a tunicát. A szövegrészek végén található sok lakúna miatt nem világos hogyan, de valamiképpen sikerült kereket oldaniuk. Petronius a milésia történetekből ismerős csattanóval zárja ezt a jelenetet is. ${ }^{113}$

A jelenetben szereplő és fent elemzett tényállások alapján a jogi kifejezések petroniusi használatát illetően a következőket mondhatjuk. A XII-XV. caputban tárgyalt

${ }^{103}$ Schmeling jelzi, hogy az általános szabály, hogy ilyenkor sequestert keresnek, de egyik oldalon sincs meg a bizalom a jogi eljárás vagy bármelyik jelen lévő sequester irányában (paraszt is belemenne inkább a cserébe). Lásd Schmeling: i. m. (30. jegyz.) 39.

${ }^{104}$ Az OLD szerinti 3. jelentésben; a jogi forrásokban a HS alapján eljárásjogi szakkifejezések között említi ugyanezzel a jelentéssel.

${ }^{105}$ A depono a jogi szaknyelvben a letétbe helyezésre használt kifejezés; OLD jogi relevanciával bíró 8. jelentés: depono ige az elhagyott dolgok használatánál és 7. jelentésben jelenti azt, hogy 'letétbe helyezni'; ugyanígy a deposita vestis (Petr. Sat. XV, 5) szintén jogi értelemben fordítható, 'letétbe helyezett ruha' jelentésben.

106 A querela az OLD alapján 'panaszt', jogi szakkifejezésként valaki ellen panasz megtételének formális módját jelenti, illetve szükebb értelemben egy bizonyos panaszt, különösen a kötelesrészre jogosult személy keresetét nevezi a római jogi terminológia querelának (HS). Itt a tágabb értelmét célszerű feltételezni, mivel öröklési vitáról a történet ezen pontján még szó sincs. Vö. et liberates querella iussit pallium deponere (Petr. Sat. XV, 7).

${ }^{107}$ A iudex a római eljárásjogban az esküdtbírót jelöli, aki egyes bírót jelentett, és a peres eljárás apud iudicem szakaszában döntötte el a felek vitáját. Földi-Hamza: i. m. (5. jegyz.) 161 skk.

${ }_{108}$ A sequester a komédiákban is gyakran szerepet kap, így Plaut. Rud. 1004; Plaut. Merc. 738. Lásd Schmeling: i. m. (30. jegyz.) 43.

${ }^{109}$ Lásd Földi-Hamza: i. m. (5. jegyz.) 303 skk.; Kaser: i. m. (36. jegyz.) 385 skk., 536 skk.

${ }_{110}$ Lásd Kaser: i. m. (36. jegyz.) 434 skk.; Földi-Hamza: i. m. (5. jegyz.) 581.

111 Vö. Schmeling: i. m. (30. jegyz.) 39. Lásd OLD s. v. depono. Vö. et liberates querella iussit pallium deponere $(15,7)$

${ }^{112}$ Az etiam causas agere kifejezés a HS alapján 'egy dolgot perelni'; 'peres ügyben eljárni, beavatkozni'. A Horváth-féle müfordítás itt igen találó 'aki máskor is a peres ügyekbe bele szokottt avatkozni' (lásd Horváth: i. m. [26. jegyz.] 8.)

${ }^{113}$ Vö. Conte: i. m. (1. jegyz.) 461 skk. 
jelenetben alkalmazott jogi szakkifejezések általában precíz pontossággal kerülnek alkalmazásra, bár ezt egy neve szerint Arbiter szerzőtől el is várhatjuk. ${ }^{114}$

A jogi latin nyelvi és a köznapi nyelvi rétegeket cserélgeti, és bár a jogi szakszavak többségét pontosan használja, előfordul, hogy nem jogi kifejezést alkalmaz jogi szituáció leírására (quo iure; querela, néha a depono ige használata). ${ }^{115} \mathrm{Az}$ egyes kifejezéseknél gyakran nem könnyű eldönteni, hogy szűkebb vagy tágabb értelemben kell-e értelmezni azokat, sőt Petronius a szavak esetleges kétértelműségét is kihasználja a tudatosan alkalmazott homályos megfogalmazásokkal. A jogi latin nyelv néha már túlzott használata (XV. caput), vagy egyenesen kifigurázása (XIV, 2) mind a nyelvi karikatúra része.

Petronius nemcsak a jogi szakkifejezéseket, hanem a római jogi szabályokat is felhasználja a jelenetben. A jogi tényállások négy csoportját és ennek megfelelően a jogi szabályozás három nagyobb és több kisebb területét érinti a jelenetben (l. a táblázatot a következő oldalon).

A válasz arra a kérdésre, hogy a jelenet vajon az elbeszélőnek, Encolpiosnak amúgy kétes - műveltségéről tesz-e tanúbizonyságot, éppúgy lehet igen, mint nem. Az elbeszélő jogban való jártasságát tükrözi ugyan a jogi latin kifejezések pontos használata, ugyanakkor Encolpios jellemét ismerve, és akár szónoki beszédére, akár megnyilvánulásaira tekintettel, amelyek Trimalchio lakomáján hangzanak el, túlzott precizitását inkább egyfajta petroniusi iróniának kell tekinteni.

Petroniusnál, szemben Iuvenalis jellemzően (és tudatosan) téves jogi szóhasználatával és téves jogi utalásaival, a humor forrásaként nem utolsósorban a jogi szabályozás kifigurázása szolgál. Petronius nem tévesen hivatkozik jogintézményekre, hanem az egyes jogi szituációkat alakítja úgy, hogy kellő mennyiségű irónia és helyzetkomikum kíséretében az olvasót szórakoztassa. A jogi latin nyelvet és a római jogot a humor kellékeként alkalmazó szatíraíró az egész Satyricon fényében helyenként már-már jogászi precizitásával teszi stilárisan is egyedivé a jelenetet.

${ }^{114}$ Ez alighanem a legmerészebb kérdés a jelenet kapcsán, hogy a Petronius nevében szereplő Arbiter jelző véletlen-e. Az Arbiter cognomen Conte szerint a Satyricon kézirati hagyományában járult Petronius nevéhez, és egy Tacitus-hellyel szokás összefüggésbe hozni, mely arbiter elegantiae-nek nevezi Petroniust. Lásd Conte: i. m. (1. jegyz.) 453 sk.; Vout: i. m. (4. jegyz.) 101 skk.; Rose: i. m. (4. jegyz.) 40 skk.; Sullivan: i. m. (4. jegyz.) 30 skk.; Courtney: i. m. (4. jegyz.) 5 skk. Az arbiter a római eljárásjog kapcsán két különböző típusú bírót jelölhet. Egyfelől a praetor által kinevezett ún. „becslő” bíró (arbiter datus), aki bizonyos eljárásokban (actiones arbitrariae), ahol szakértelemre van szükség, egyesbíróként, ill. háromfős testületben jár el. Másfelől ún. választottbíróról (arbiter ex compromisso) lehet szó (lásd Földi-Hamza: i. m. (5. jegyz.) 161 skk, 544 skk.) Mindkét esetben olyan szerzőt feltételezne, aki jártas a jogi eljárásokban, ismeri a jogot, és ennek hatása érezhető a jogi kifejezések használatán. Ennél talán kevésbé merészebb azt feltételezni, hogy az elbeszélőnek, Encolpiosnak a műveltsége kiterjed a jog ismeretére, mely totális iróniába fordítja az egész jelenetet. Lásd Conte: i. m. (12. jegyz.) 35 skk. Vö. Rimell: i. m. (10. jegyz.) 70 skk.; Courtney: i. m. (4. jegyz.) 7 skk.

115 A XIII, 2-ben szereplő depositum esse inviolatum vidit kitételnél a depositum nem jogi értelemben szerepel, mint később a XV, 2; XV, 5 helyeken. A depono-t szó szerint fordítva, arra utal, hogy valahova letették a dolgot és ott felejtették. A ThLL és OLD alapján tágabban értelmezve a depono igét, valószínűleg a tunica elhagyásáról van szó. Lásd Schmeling: i. m. (30. jegyz.) 38. 


\begin{tabular}{|l|l|l|}
\hline \multicolumn{1}{|c|}{$\begin{array}{c}\text { A jelenet fóbb } \\
\text { jogintézményei }\end{array}$} & Egyéb érintett szabályok & \multicolumn{1}{|c|}{ Jellemző jogi szakkifejezések } \\
\hline $\begin{array}{c}\text { 1) az adásvételi } \\
\text { szabályok } \\
\text { (emptio rei alienae } \\
\text { et suae })\end{array}$ & $\begin{array}{l}\text { érvénytelenségi szabályok; } \\
\text { "büntetőjogi” szabályok }\end{array}$ & $\begin{array}{l}\text { rerum venalium; raptum latroci- } \\
\text { nio pallium; emptor; } \\
\text { vendito; emere, quamvis nostrum } \\
\text { sit }\end{array}$ \\
\hline $\begin{array}{l}\text { 2) igényérvényesítés, } \\
\text { eljárásjog }\end{array}$ & $\begin{array}{l}\text { interdiktális birtokvédelem; } \\
\text { vadimonium / testimonium; } \\
\text { praefectus vigilum; } \\
\text { "büntetőjogi" szabályok }\end{array}$ & $\begin{array}{l}\text { vindico; iure civili dimicandum } \\
\text { (esse); ad interdictum venirent; } \\
\text { in ambiguam litem descendere } \\
\text { (lis); iudicium; advocati nocturni; } \\
\text { flagito; iudex; querellam inspice- } \\
\text { ret; causas agere; metu criminis; } \\
\text { venio ad constitutum }\end{array}$ \\
\hline 3) sequestrum & $\begin{array}{l}\text { letétbe helyezés; } \\
\text { felmutatási kötelem }\end{array}$ & $\begin{array}{l}\text { depono; deposita vestris; pallium } \\
\text { exhibiturum }\end{array}$ \\
\hline
\end{tabular}

\title{
SUMMARY
}

The interaction between classical Latin literary language and Latin legal language developed by Roman iurisconsulti, is a less studied field standing on the border of Roman law and Latin literature, which conceals many unanswered questions. The emergence of legal terminology in classical Latin literature is apt to look to the non-lawyer like a strange phenomenon, which could become interesting to readers by its veiling and often dubious interpretability. This study deals with the role and function of legal terminology in the XII-XV chapters of Petronius' Satyricon through an analysis of law-related facts. The scene at the forum reveals the true nature of Petronius' intent, and also leaves a question to the reader. Whether the key to understand the situation lies within the rules and interpretations of Roman law, or we shall consider that it is merely the intention of the writer? There is a contrast between the precision of Roman legal terminology and the irony of Petronius, which exploits Latin legal language in purpose of creating a specific way of humour.

Keywords: Petronius, Satyricon, satire, Roman law, Latin legal language, law and literature, law as source of humour

\author{
NeMES SZILvia \\ ELTE ÁJK Állam- és Jogtudományi Doktori Iskola \\ Állam- és Jogtudományi Doktori Program \\ 1053 Budapest, Egyetem tér 1-3. \\ nszilvie@gmail.com
}

